3. Лакида П.І. Нормативи оцінки компонентів надземної фітомаси дерев головних лісотвірних порід України / П.І. Лакида та ін. - К. : Вид. дім "ЕКО-інформ". - 2011. - 192 с.

4. Лакида П.І. Нормативи оцінки компонентів надземної фітомаси деревостанів головних лісотвірних порід України / П.І. Лакида та ін. - Корсунь-Шевченківський : Вид-во ФОП В.М. лісотвірних порід Україн $/$
Гавришенко. - 2013. $-457 \mathrm{c}$.

5. Швиденко А.З. Таблицы и модели хода роста и продуктивности насаждений основных лесообразующих пород Северной Евразии : нормат.-справ. матер. / А.З. Швиденко, Д.Г. Щепащенко, С. Нильссон, Ю.И. Булуй. - Изд. 2-ое, [перераб. и доп.]. - М. : Изд-во "Московская типография № 6". - 2008. - 888 с.

6. Швиденко А.З. Материалы к познанию современной продуктивности лесных экосистем России / А.З. Швиденко, Д.Г. Щепащенко, С. Нильссон // Базовые проблемы перехода к устойчивому управлению лесами России - учёт лесов и организация лесного хозяйства : матер. междунар. семинара, (6-7 декабря 2007 г.); Ин-т леса им. В.Н. Сукачева. - Красноярск : Изд-во
СО РАН. - 2007. - С. 7-37.

7. Швиденко А.З. Система моделей роста и динамики продуктивности лесов России. - Ч. 2. Таблицы и модели биопродуктивности / А.З. Швиденко, Д.Г. Щепащенко, С. Нильссон, Ю.И. Булуй // Лесное хозяйство : межвуз. сб. науч. тр. - 2004. - № 2. - С. 40-44.

8. Швиденко А.З. Чистая первичная продукция лесных экосистем России: новая оценка / А.З. Швиденко, Д.Г. Щепащенко, Е.А. Ваганов, С. Нильссон // Доклады Академии Наук : сб. науч. тр. - 2008. - Т. 421, № 6. - С. 822-825.

9. Shvidenko A. Semi-empirical models for assessing biological productivity of Northern Eurasian forests / A. Shvidenko, D. Schepschenko, S. Nilsson, Y. Bouloui // Ecological Modelling. - 2007. Vol. 204. - Pp. 163-179.

Блыщик В.И. Чистая первичная продукция насаждений ольхи клейкой Украинского Полесья

Осуществлена оценка чистой первичной продукции ольховых насаждений по классам бонитета. Самые высокие показатели чистой первичной продукции характерны для средневековых насаждений ольхи клейкой в Ia -II, а для переспелых - в III-IV лассах бонитета. Таксе установлены особенности динамиги чистой первичной продукции и проаналин лирования динамики фитомассы, которая была разработана в Международном институте прикладного системного анализа (IIASA, Австрия). За основу использованы таблицы хода роста модальных древостоев и модели компонентов фитомассы ольховых насаждений.

Ключевые слова: чистая первичная продукция, ольха клейкая, Украинское Полесье, компоненты фитомассы, класс бонитета, структура, динамика.

Blyshchyk V.I. Net Primary Production of Black Alder Stands of Ukrainian Polissya

The estimation of Net Primary Production of alder stands by site index is presented. The middle-aged alder stands of I ${ }^{\mathrm{a}-}$ II site index as well as over-mature of III - IV site index have the highest values of Net Primary Production. Some specific features of dynamics of Net Primary Production are also studied and its structure is analyzed. The research was carried out by the method of modeling the dynamics of live biomass developed at the International Institute for Applied Systems Analysis (IIASA, Austria). Yield tables for modal stands and models of live biomass fractions of alder stands as the basis for calculation of Net Primary Production are applied as the basis of the research.

Keywords: Net Primary Production, black alder, Ukrainian Polissya, fractions of live biomass, site index, structure, dynamics.

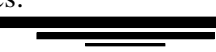

Acnip. I.I. Гнатишин ${ }^{l}$ - НЛТУ Украйни, м. Львів

\section{ВОДНИЙ РЕЖИМ ЛИСТЯ В УМОВАХ}

УРБАНІЗОВАНОГО СЕРЕДОВИЩА

Досліджено водний режим листкової тканини рослин, що зростають у різних екологічних умовах. Визначено та здійснено порівняння добового циклу транспірації у листі найпоширеніших порід дерев у Самборі: берези повислої, горобини звичайної та клена гостролистого. Виявлено залежність інтенсивності транспірації, оводненості тканин листка та дефіциту вологи від умов місць зростання. Досліджено вплив вологості повітря та вологості грунту на дефішит вологи в листі. Встановлено зв'язок між температурою повітря та нагіван кожної з порід, залежно від умов середовища.

Ключові слова: транспірація, дефіцит вологи, оводненість тканин листка, урбанізоване середовище.

Насадження загального користування є важливим компонентом формування урболандшафтів. У малих містах вони представлені парками та скверами, що виконують важливу екологічну та санітарно-гігієнічну функції. Враховуючи, що одним з характерних факторів міського середовища є підвищена температура за порівняно низької вологості, основною метою дослідження $є$ виявлення порушень водного режиму найпоширеніших деревних порід в умовах II (парк) та III (сквер) еколого-фітоценотичних поясів (далі ЕФП) [2, 3]. Вивчення водного режиму листя охоплює визначення рівня інтенсивності транспірації, оводненості листка та дефіциту вологи [1]

Об'єкт, предмет та методи дослідження. Об'єктами досліджень - насадження міського парку та скверу Пам'яті, що розташовані поряд (II та III ЕФП). Для аналізу брали листки найпоширеніших порід: берези повислої (Betula pendula Roth.), горобини звичайної (Sorbus aucuparia L.) та клена гостролистого (Acer platanoides L.). Інтенсивність випаровування та дефіцит вологи в листі визначали за таких умов: середня температура повітря $+32^{\circ} \mathrm{C}$, відносна вологість повітря $60 \%$, час доби в період максимальної інсоляції- з 12 по 14 год, освітленість 12000 люксів.

Інтенсивність транспірації визначали за методом швидкого зважування, за Л.А. Івановим [6], який грунтується на врахуванні зміни маси зрізаного транспіруючого листка за короткий проміжок часу, що дає змогу зафіксувати стан насичення листка водою, в тому стані, в якому він перебував на дереві. Листя для дослідження брали з південної сторони крони на одній висоті від поверхні землі. Зрізане листя зважували не пізніше ніж через 30 с на електронній вазі $з$ точністю до 1 мг. Дослід продовжувався з інтервалом через 2, 4 та 24 год. Спад у масі листя між першим і наступними зважуваннями виявив кількість випаруваної вологи за цей період. Вміст загальної води у листі - оводненість, вираховували у відсотках як відношення маси сухого листка до сирої наважки. Для цього взірці листя після останнього зважування поміщали в сушильну камеру і зберігали там до повного випаровування вологи за температурі $100^{\circ} \mathrm{C}$. Для визначення дефіциту вологи проби занурювали у воду кімнатної температури на 30 хв, потім просушували у серветках, щоб позбутися води на поверхні. Розрахунок дефіциту вологи виконували у відсотках від маси листків, насичених водою $[4,5]$.

Наук. керівник: проф. В.П. Кучерявий, д-р с.-г. наук

1. Лісове та садово-паркове господарство 
Одночасно з інтенсивністю транспірації визначали температуру та відносну вологість повітря на висоті 1 м за сухим та зволоженим термометром психрометра Ассмана. За допомогою лазерного термометра заміряли температуру листя та підстильної поверхні. Температуру грунту виміряли грунтовим термометром на глибині 10 см. У цьому ж місці фіксували вологість грунту за допомогою вологоміру.

Результати дослідження та обговорення. Дослідження здійснено у міському парку та сквері (рис.), зокрема, визначено температуру повітря, грунту та підстильної поверхні, а також температура нагрівання листової пластини, вологість повітря та вологість грунту. Заміри проводено під кроною дерев.

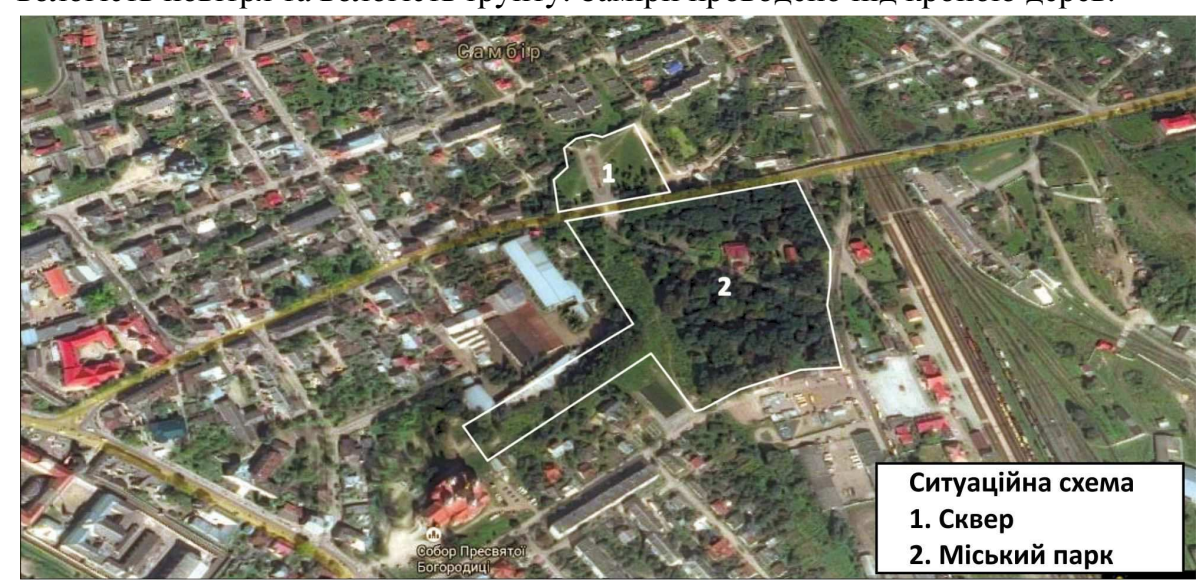

Рис. Розташування парку та скверу в середовищі міста

У сквері Пам'яті, у зв'язку з його меморіальним та транзитним призначенням, мощення займає 27 \% (загальна площа 1,5 га). Насадження представлені солітерами та алейними посадками. Проекція крон становить $30 \%$, що робить простір скверу відкритим з рівномірною сонячною інсоляцією. Це пояснює незначну диференціацію показників температури та вологи (табл. 1). Температура повітря під наметом дерев змінюється в межах $34-35^{\circ} \mathrm{C}$. При цьому листя прогрівається до $32,5-34^{\circ} \mathrm{C}$, підстильна поверхня $-49,9-51,5^{\circ} \mathrm{C}$, температура грунту на глибині $10 \mathrm{~cm}-34-35^{\circ} \mathrm{C}$. Дефіцит вологи в листі залежить від відносної вологості повітря та грунту. За відносної вологості повітря $65 \%$ та вологості грунту в межах 34,6-37 \% найбільший дефіцит вологи є в листі горобини звичайної - $44 \%$ та берези повислої - 36,36 \%, а найнижчий є у клена гостролистого - 21,95\% (табл. 2). Оводненість тканин листя змінюється в межах 49-59 \%. Найінтенсивніше транспірує горобина, що свідчить про її пристосованість до ксерофітних умов зростання.

Якщо у сквері мікрокліматичні показники не сильно різняться, то у парку, де інсоляційні потоки не є однорідні, спостерігається істотна різниця умов місцезростання та показників оводненості листової пластини. Площа парку становить 11 га, з яких $67 \%$ території є вегетуючою. Озеленення парку представлене насадженнями різної зімкнутості, внаслідок чого в кожній асоціації спостерігається власний мікроклімат. Для досліду обрано насадження з різною зімкнутістю.
Табл. 1. Показники температур у насадженнях

\begin{tabular}{|c|c|c|c|c|c|c|}
\hline Порода & $\begin{array}{l}\text { Темпе- } \\
\text { ратура } \\
\text { листка, } \\
{ }^{\circ} \mathrm{C}\end{array}$ & $\begin{array}{c}\text { Температура } \\
\text { повітря під } \\
\text { наметом де- } \\
\text { рева, }{ }^{\circ} \mathrm{C}\end{array}$ & $\begin{array}{l}\text { Температура } \\
\text { підстильної } \\
\text { поверхні, }{ }^{\circ} \mathrm{C}\end{array}$ & $\begin{array}{c}\text { Tемпера- } \\
\text { тура } \\
\text { грунту, } \\
{ }^{\circ} \mathrm{C}\end{array}$ & $\begin{array}{l}\text { Вологість } \\
\text { повітря, \% }\end{array}$ & $\begin{array}{c}\text { Вологість } \\
\text { грунту, \% } \\
\text { на глибині } \\
10 \mathrm{~cm}\end{array}$ \\
\hline $\begin{array}{c}\text { Береза } \\
\text { повисла }\end{array}$ & $\frac{29,4}{34}$ & $\frac{30,0}{34,8}$ & & $\frac{25,0}{34,0}$ & $\frac{60,0}{56,0}$ & $\frac{46,6}{37,0}$ \\
\hline $\begin{array}{c}\text { Горобина } \\
\text { звичайна }\end{array}$ & $\frac{30,1}{32,5}$ & $\frac{32,0}{35,0}$ & $\frac{46,6}{49,9}$ & $\frac{32,0}{35,0}$ & $\frac{58,0}{56,0}$ & $\frac{47,0}{34,6}$ \\
\hline $\begin{array}{c}\text { Клен } \\
\text { гостролистий }\end{array}$ & $\frac{27,8}{32,7}$ & $\frac{29,4}{34,0}$ & $\frac{24,9}{50,0}$ & $\frac{23,0}{35,0}$ & $\frac{71,0}{56,0}$ & $\frac{55,8}{35,6}$ \\
\hline
\end{tabular}

Примітка: чисельник - у парку, знаменник - у сквері.

Галявина з горобиною, як солітером, та рясним вкриттям підстильної поверхні злаковими травами. Цей простір характеризується найінтенсивнішою інсоляцією, тому температурні показники тут найвищі в парку, проте значно нижчі, ніж у сквері. За температури повітря $32^{\circ} \mathrm{C}$ листя прогрілось до температури $30,1^{\circ} \mathrm{C}$, підстильна поверхня до $-42^{\circ} \mathrm{C}$, а грунт на рівні $10 \mathrm{~cm}-$ до $32^{\circ} \mathrm{C}$. Відносна вологість повітря становить $58 \%$, а грунту - $47 \%$. Дефіцит вологи в листі горобини на відкритій ділянці становить 27,8 \%, а інтенсивність транспірації найвища серед показників у парку та вдвічі перевищує дані після випаровування вологи з листя горобини у сквері. Оводненість листя становить 61,9% (табл. 2).

Табл. 2. Водний режси листя у насадженнях загального користування

\begin{tabular}{|c|c|c|c|c|c|c|c|c|c|}
\hline \multirow{3}{*}{ Порода } & \multirow{3}{*}{$\begin{array}{c}\text { Маса } \\
\text { листка, } \\
\text { Г }\end{array}$} & \multicolumn{6}{|c|}{$\overline{\text { Транспірація }}$} & \multirow{3}{*}{$\begin{array}{l}\text { Дефіцит } \\
\text { вологи в } \\
\text { листі, \% }\end{array}$} & \multirow{3}{*}{$\begin{array}{c}\text { Оводне- } \\
\text { ність } \\
\text { листя, \% }\end{array}$} \\
\hline & & \multicolumn{2}{|c|}{ через 2 год } & \multicolumn{2}{|c|}{ через 4 год } & \multicolumn{2}{|c|}{ через 24 год } & & \\
\hline & & гр. & $\%$ & гр. & $\%$ & гр. & $\%$ & & \\
\hline \multirow{2}{*}{$\begin{array}{c}\text { Береза } \\
\text { повисла }\end{array}$} & 1,1 & 1,00 & 9,09 & 0,99 & 10,00 & 0,56 & 49,10 & 30,00 & 68,20 \\
\hline & 1,97 & 1,88 & 4,57 & 1,87 & 5,10 & 1,52 & 22,80 & 36,36 & 49,20 \\
\hline \multirow{2}{*}{$\begin{array}{l}\text { Горобина } \\
\text { звичайна }\end{array}$} & 0,42 & 0,33 & 21,40 & 0,32 & 23,80 & 0,20 & 52,40 & 27,8 & 61,90 \\
\hline & 1,2 & 1,05 & 12,50 & 1,03 & 14,20 & 0,60 & 50,00 & 44,4 & 59,20 \\
\hline \multirow{2}{*}{$\begin{array}{l}\text { Клен гос- } \\
\text { тролистий }\end{array}$} & 0,58 & $\underline{0,53}$ & 8,60 & $\underline{0,49}$ & 15,50 & $\underline{0,30}$ & 48,30 & 12,12 & 67,20 \\
\hline & 0,96 & 0,90 & 6,27 & 0,86 & 10,40 & 0,52 & 45,80 & 21,95 & 50,00 \\
\hline
\end{tabular}

Примітка: чисельник - у парку, знаменник - у сквері.

Напіввідкритий простір представлений асоціацією беріз з проективним покриттям крон $40 \%$, та переважаючими злаками у трав'яному покриві. Температура повітря тут на $2{ }^{\circ} \mathrm{C}$ нижча, ніж на галявині, а відносна вологість повітря менша і становить $60 \%$. Листя берези за цих умов прогріте до $29,4^{\circ} \mathrm{C}$. Температура підстильної поверхні становить $46,6^{\circ} \mathrm{C}$. Температура грунту становить $25^{\circ} \mathrm{C}$, вологість - 46,6\%. Швидкість транспірації в листі берези вдвічі вища, ніж в умовах скверу. Оводненість листових тканин - 68,2 \%, а дефіцит вологи в листі - $30 \%$.

Закритий простір представлений асоціацією дерев, де проективне покриття становить $70 \%$. Трав'яне вкриття відсутнє. Цей тип простору характеризується найнижчими температурними показниками та найвищим вмістом вологи у повітрі - $71 \%$. Це пояснює найменший дефіцит вологи $(12,12 \%)$ у листі клена гостролистого. Оводненість тканин листя є високою- 67, 2 \%, а відповідно, дефіцит вологи в листі становить всього 12,12 \%, що є найнижчим показником у парку.

1. Лісове та садово-паркове господарство 
Висновки. Температурний та вологісний режими повітря та грунту, які залежать від рівня урбанізації (парк-сквер) та підстильної поверхні, як свідчать дослідження, значною мірою впливають на фізіологічні показники: транспірацію, обводнення та дефіцит вологи. Встановлено зростання диференціації температур від закритого простору до відкритої галявини та скверу і відповідне зменшення вологості повітря та грунту. Із збільшенням вологості повітря зменшується дефіцит вологи у листі. Дефіцит вологості листя обернено пропорційний до процесу транспірації. За даними, наведеними в табл. 2, можна стверджувати, що випаровування вологи з листя досліджуваних порід повільніше відбувається в умовах скверу. Наприклад, у деяких зразках показники транспірації між листками, взятими з дерев парку та зі скверу, різняться майже наполовину. Щодо вмісту води у тканинах листя, то у взірцях листків з парку він значно вищий. Оводненість $є$ обернено пропорційною до дефіциту вологи в листі для кожної породи.

\section{Література}

1. Горишіна Т.К. Екологія рослин : навч. посібн. / Т.К. Горишіна. - К. : Вид-во "Вища шк.", 1979. $-126 \mathrm{c}$

2. Кучерявий В.П. Урбоекологія : навч. посібн. / В.П. Кучерявий. - Львів : Вид-во "Світ". $2002,440 \mathrm{c}$.

3. Кучерявий В.П. Екологія : навч. посібн. / В.П. Кучерявий. - Львів : Вид-во "Світ". 2001. $-500 \mathrm{c}$.

4. Сказкин Ф.Д. Определение интенсивности транспирации при помощи торсионных весов практикум по физиологии растений / Ф.Д. Сказкин, Е.И. Логвиновская, М.С. Миллер В.В. Аникеев. - М. : Изд-во "Советская наука", 1958. - С. 75-78.

5. Практикум по агрохимии : учеб. пособ. - Изд. 2-ое, [перераб. и доп.] / под ред. акад. РАСХН В.Г. Минеева. - М. : Изд-во МГУ. - 2001. - 689 с.

6. Туманов, В.Н. Малый практикум по физиологии растений / В.Н. Туманов, С.Л. ЧирукГродно : Изд-во ГрГУ. - 2012. - С. 133.

Гнатишин И.И. Водный режим листьев в условиях урбанизированной среды

Исследован водный режим листовой ткани растений, обитающих в различных экологических условиях. Определено и осуществлено сравнивание суточного цикла транспирации в листьях наиболее распространенных пород деревьев в Самборе: березы повисшей, рябины обыкновенной и клена остролистного. Определена зависимость инповисшей, рябины обыкновенной и клена остролистного. Определена зависимость интенсивности транспирации, оводненности тканей листья и дефицита влаги от условий
произрастания. Исследовано влияние влажности воздуха на дефицит влаги листьев. Успроизрастания. Исследовано влияние влажности воздуха на дефицит влаги листьев. Ус-
тановлена связь между температурой нагрева воздуха, листовой пластины, подстилающей поверхности и почвы по каждой из пород, в зависимости от условий среды.

Ключевые слова: транспирация, дефицит влаги, оводненность тканей листьев, урбанизированная среда.

\section{Gnatyshyn I.I. Water Regime of Leaves in Urban Space}

Water regime of leaves in different eco-zones is described. Daily cycle and transpiration in leaves of most common species such as Betula pendula, Sorbus aucuparia and Acer platanoides is determined and compared. The intensity of transpiration, water content in leaf tissue, and moisture deficit in leaf tissue are researched. The effect of humidity on leaf moisture deficit is determined. Connection between the air temperature, leaf plate warming, land surfaces and soil for each species is defined.

Keywords: intensity of transpiration, shortage of moisture, water content in leaf tissue, urban space.

\section{УДК 630*181:635 \\ Здобувач І.Я. Тимочко; \\ доц. О.М. Гриник, канд. с.-г. наук-НЛТУ Украӥни, м. Львів \\ РЕЖИМИ ЕКСПЛУАТАЦІЇ ТА СХОЖІСТЬ НАСІННЯ ALLIUM URSINUM L. У РІЗНИХ ТИПАХ ЛІСУ}

Представлено результати досліджень заготівлі сировини надземної частини цибулі ведмежої за різних режимів (проводили видалення частки на рівні 25, 50, 75 та $100 \%$ від загальної фітомаси рослин) у різних типах лісорослинних умов. Встановлено, що грунтова схожість, порівняно з лабораторною, є значно вищою. Усереднена лабораторна схожість пророщеного насіння, зібраного в умовах вологого груду, становила 7,3\%, а в умовах вологого сугруду - 5,3\%. Із підвищенням інтенсивності режиму експлуатації, сповільнюється розвиток особин і, відповідно, відновлення зарості. Встановлено, що із збільшенням інтенсивності експлуатації відновлення частки особин на одиниці площі знижується за режиму експлуатації 75 і $100 \%$.

Ключові слова: цибуля ведмежа, сировина, режими заготівлі, лісовий фітоценоз, онтогенез, відновлення, лабораторна і грунтова схожість насіння.

Вступ. Постійна затребуваність у лікарській та інших видах рослинної сировини зумовлює потребу у визначенні потенційно можливих запасів багатьох видів рослин, зокрема і цибулі ведмежої, сировину якої щорічно масово заготовляють як ранньовесняний вітаміноз. Сировину лікарських рослин в Україні отримують шляхом заготівлі у природних фітоценозах та шляхом культивування у спеціалізованих господарствах. Заготівля у природних місцезростаннях має низку переваг, наприклад, не потребує додаткових витрат на вирощування. Постійна та неконтрольована експлуатація заростей трав'яних рослин призводить до негативних наслідків та їх масового зникання із трав'яного вкриття. Своєю чергою, видалення екземплярів окремого виду із рослинного вкриття може стати причиною дисбалансу у фітоценозі. При цьому можуть порушуватися взаємозв'язки між усіма компонентами - як біотичними (фітоценоз, зооценоз, мікробоценоз), так і абіотичними.

Постановка проблеми дослідження та її актуальність. Для науково-господарської практики велике значення має не тільки загальне збільшення об'єму заготівлі лікарської сировини трав'яних видів, але й збільшення збирання сировини визначених видів, які користуються попитом. Ці види (із підвищеним попитом) здебільшого мають обмежені запаси сировини або ж недостатньо вивчена потенційна здатність штучного збільшення сировинної бази шляхом докорінного поліпшення природних заростей, або ж агротехнічного вирощування $[1-4,6]$.

Деякі фітоценози, де зростають рослини, можуть бути непридатні через важкодоступність або забрудненість території тяжкими металами чи різного роду радіонуклідами. Але, все таки, основним лімітуючим чинником заготівлі $\epsilon$ виснаження запасів внаслідок нерегламентованої господарської діяльності людини. Рослини можуть зникати із трав'яного вкриття через виконання меліоративних робіт, суцільне вирубування деревостанів, посилений випас худоби та сінокосіння в недозволених місцях, витоптування рослинного вкриття, нерегламентованого користування та ін. Також під час заготівлі сировини допускають низку порушень у технології заготівлі. Ця проблема стосується багатьох видів лікарських трав'яних рослин, що мають попит на різні види заготовлюваної сировини. Тому й виникла потреба у з'ясуванні особливостей відтворення дослі- 